\title{
Filtration Issue
}

National Cancer Institute

\section{Source}

National Cancer Institute. Filtration Issue. NCI Thesaurus. Code C62986.

Problem associated with the process of passing a substance through a porous medium, e.g., a blood clot filter for the removal of suspended matter. 